\title{
Mitochondrial DNA variation and Haldane's rule in the Papilio glaucus and $P$. troilus species groups
}

\author{
FELIX A. H. SPERLING \\ Section of Ecology and Systematics, Corson Hall, Cornell University, Ithaca, NV 14853-2701, U.S.A.
}

\begin{abstract}
Variation in mitochondrial DNA (mtDNA) was surveyed, using restriction endonucleases, in all species of the Papilio glaucus and P. troilus groups (Lepidoptera: Papilionidae). Phylogenetic and distance relationships of mtDNA generally confirmed traditional species limits in the two species groups and compared favourably with a prior survey of their allozymes. The most notable exceptions were $P$. rutulus and $P$. eurymedon, which share their mtDNA, yet maintain numerous morphological and ecological distinctions in sympatry. In organisms with heterogametic females, like the Lepidoptera, the deficiencies of hybrid females that are expected on the basis of Haldane's rule should lead to congruence of mtDNA variants with species boundaries. In the $P$. glaucus group, the extent of mtDNA differences between species pairs generally coincided with the extent of the Haldane effect, as well as with the presence of major species differences on sex chromosomes (X effect).
\end{abstract}

Keywords: allozymes, introgression, phylogeny, sex linkage, speciation.

\section{Introduction}

Mitochondrial DNA (mtDNA) has become one of the most commonly employed markers for determining genetic relationships among individuals and species (Avise et al. 1987; Harrison, 1991). Its generally maternal inheritance, simple structure, small size, rapid evolution and ease of isolation have made the molecule particularly amenable to population genetic and phylogenetic analysis (Avise, 1989, 1991). However, as with any single cluster of tightly linked genes, the phylogeny of mtDNA may not correspond to the average gene phylogeny of the organisms involved. It remains important to establish the effectiveness of mtDNA as a phylogenetic marker, and to investigate conditions under which variation in the molecule may fail to indicate species boundaries.

Since mitochondrial DNA is almost exclusively maternally inherited (Avise, 1991; but see Zouros et al., 1992), elimination of hybrid females should lead to congruence of species boundaries and the distribution of mtDNA variants. Some animals, such as butterflies and birds, show higher rates of sterility or inviability in

Present address: Department of Biology, Gendron Hall, University of Ottawa, Ottawa, Ontario, Canada K1N 6N5.
$F_{1}$ females than in $F_{1}$ males and this phenomenon is correlated with the fact that females are the heterogametic sex in these organisms (Haldane, 1922; Coyne \& Orr, 1989; Coyne et al. 1991; but see Read \& Nee, 1991). When the Haldane effect is strong $\left(F_{1}\right.$ females are substantially less viable or fertile than males), and other biological factors like selection are equal, the distribution of different mtDNA haplotypes should conform better to species boundaries in zones of hybrid interactions than should most nuclear genes.

The X effect, which Coyne \& Orr (1989) have defined as a disproportionate tendency for genes that are important to hybrid sterility or inviability to occur on sex chromosomes, is correlated with the Haldane effect. The mechanism leading to the Haldane efffect or X effect remains uncertain (Coyne et al., 1991; Frank, 1991). Both effects may relate to the fact that sex-linked alleles are more exposed to selection, causing differences to accumulate faster than for autosomal alleles (Charlesworth et al., 1987; Coyne \& Orr, 1989). If the Haldane effect and X effect are real and associated with differential selection against individuals of the heterogametic sex, then in species with heterogametic females both effects should be correlated with the presence of mtDNA differences between species. 
I investigated mtDNA variation in swallowtail butterflies of the Papilio glaucus group (six species) and Papilio troilus group (three species), all of which are restricted to North America. Morphological comparisons among members of the $P$. glaucus species group were carried out by Brower (1959a), and Hagen et al. (1992) have elevated P. canadensis to species status. Allozymes of both species groups were analysed phylogenetically by Hagen \& Scriber (1991). In the present study, a survey of restriction site variation in mtDNA of the $P$. glaucus and $P$. troilus species groups was used to address two questions: (i) do mtDNA differences occur between species and are they correlated with the Haldane effect or X effect? (ii) how well does the mtDNA phylogeny coincide with prior phylogenetic hypotheses, particularly those of Hagen \& Scriber (1991)?

\section{Methods}

One or a small number of adult swallowtail butterflies were collected for each species and kept frozen at $-80^{\circ} \mathrm{C}$ until use. Mitochondrial DNA restriction sites were mapped on a total of 31 specimens representing different localities or species (Table 1). Each haplotype

Table 1 Specimens examined, grouped by taxon. $(\mathrm{CA}=$ California, $\mathrm{FL}=$ Florida, $\mathrm{WA}=$ Washington $)$

Taxon $(n)$. Locality 1 (haplotype); Locality 2 (haplotype);...

P. glaucus (4). Potomac, Maryland (G1); Great Falls, Maryland (G1); Ocala State Forest, FL (G1); Stone Co., Arkansas (G2)

P. alexiares garcia (1). Tamaulipas, Mexico (G3)

P. canadensis (5). Richford, New York (G4); Bragg Creek, Alberta (G4); Fairbanks, Alaska (G5); Madison, Wisconsin (G6); Black Hills, South Dakota (G7)

P. rutulus (6). Orcas Isl., WA (R1); Alpine Co., CA (R1); Columbia R., Oregon (R2); Mono Co., CA (R2); Nevada Co., CA (R2); San Francisco, CA (R3)

P. eurymedon (5). Alpine Co., CA (R4); Mono Co., CA (R5); Orcas Island, WA (R6); Nevada Co., CA (R7); Los Angeles Co., CA (R8)

P. multicaudatus (2). Black Hills, South Dakota (MU1); Okanogan Co., WA (MU2)

P. troilus ilioneus (2). Ocala State Forest, FL (T1); Highland St. Park, FL (T1)

P. troilus troilus (2). Blue Ridge, Virginia (T2); Fayette Co., Tennessee (T2)

P. palamedes palamedes (2). Ocala State Forest, FL (PA1); Highland State Park, FL (PA2)

$P$. palamedes leontis (1). Tamaulipas, Mexico (PA3)

P. pilumnus (1). Tamaulipas, Mexico (PI) was designated with a separate code, to distinguish mtDNAs from the species that contain them. Voucher specimens of the wings and/or abdomen of each specimen are deposited as lot no. 1204 in the Entomology Collection of Cornell University.

Total DNA was extracted from the thoraces of single butterflies using the protocol of Harrison et al. (1987). Small aliquots (generally $1 / 100$ th of the original DNA extracted) were digested separately with 17 restriction endonucleases: BamHI, BclI, BglII, Bst $\mathrm{BI}$, BstEII, Bst NII, ClaI, EcoRI, HaeIII, HindIII, MspI, PstI, PvuII, ScaI, SstI, XbaI and XhoI. Fourteen of the enzymes recognize sequences of $6 \mathrm{bp}$, HaeIII and MspI recognize sequences of $4 \mathrm{bp}$ and $B s t \mathrm{NI}$ recognizes the sequence $\mathrm{CC}(\mathrm{A} / \mathrm{T}) \mathrm{GG}$. DNA fragments were separated in 0.8 per cent agarose gels and transferred to nylon filters with $0.4 \mathrm{~N}$ sodium hydroxide. Pure mtDNA was separated from Papilio polyxenes total DNA by differential centrifugation in a $\mathrm{CsCl}$ gradient, and then used to probe for mtDNA on the nylon filters. $P$. polyxenes $\mathrm{mtDNA}$ was labelled with ${ }^{32} \mathrm{P}$ by random priming, hybridized to DNA fragments on nylon filters, and visualized by autoradiography.

Fragment sizes were estimated by comparison to lanes with a one kilobase size standard (New England Biolabs) and the positions of sites were determined by double digestions. Sequence divergence was estimated with the iterative estimation technique of Nei \& Tajima (1983). Phylogenetic trees were obtained by analysing presences and absences of restriction sites as unordered characters using PAUP $3.0 \mathrm{q}$ (Swofford, 1991).

\section{Results}

\section{Haplotypes and genetic divergences}

A total of 23 different haplotypes was found among the 32 maternal lineages surveyed. The seven most divergent haplotypes are shown in Fig. 1 and minor haplotypes are described in the figure legend. Except for $P$. pilumnus, which had an insertion of 0.8 kilobases, all haplotypes had a size of about 15.2 kilobases. No size variation or site polymorphism was detected within individuals. A total of 102 restriction sites was detected, with a range of $42-50$ per individual. The mean number of sites was 46.6 per individual, which represents about 1.7 per cent of the mtDNA genome.

In the $P$. glaucus group, four groups of haplotypes had divergences of 1 per cent or less. These corresponded to the mtDNAs of: 1 . P. glaucus $+P$. alexiares; 2. P. canadensis; 3 . P. rutulus + P. eurymedon; and 4. P. multicaudatus. One haplotype of $P$. rutulus (R3) was more similar to two mtDNAs of $P$. eurymedon $(\mathrm{R} 4$ and 
Fig. 1. Linearized $m t D N A$ restriction site maps of seven major haplotypes in the $P$. glaucus and $P$. troilus species groups. Haplotype designations are on the left margin. Sites that are conserved in all haplotypes are shown at the top of the figure. Letter code for restriction enzymes is as follows: $\mathrm{a}=\mathrm{BamHI}$, $\mathrm{b}=B s t \mathrm{BI}, \mathrm{c}=C l a \mathrm{I}, \mathrm{d}=$ HindIII, $\mathrm{e}=E c o \mathrm{RJ}, \mathrm{f}=B c l \mathrm{I}, \mathrm{g}=B g l \mathrm{II}$, $\mathrm{h}=$ HaeIII, $\mathrm{k}=S c a \mathrm{I}, \mathrm{m}=M s p \mathrm{I}$, $\mathrm{n}=B s t \mathrm{NI}, \mathrm{p}=P s t \mathrm{I}, \mathrm{s}=S s t \mathrm{I}, \mathrm{t}=B s t \mathrm{EII}$, $\mathrm{v}=P v u \mathrm{II}, \mathrm{x}=X b a \mathrm{I}$, and no code for $X$ ho1. Minor haplotypes are characterized as follows:

$\mathbf{G} 2=\mathrm{G} 1+\mathrm{c} 10.85-\mathrm{p} 2.90$

$\mathbf{G 3}=\mathrm{G} 1+\mathrm{h} 3.6+\mathrm{d} 4.15$;

$\mathbf{G 5}=\mathrm{G} 4-\mathrm{x} 12.0$

$\mathbf{G 6}=\mathrm{G} 4-\mathrm{f} 3.1-\mathrm{m} 7.25$

$\mathbf{G} 7=\mathrm{G} 4-\mathrm{e} 12.05-\mathrm{m} 7.25-\mathrm{m} 11.15$

$\mathbf{R} 1=\mathrm{R} 4-\mathrm{b} 12.35$;

$\mathbf{R 2}=\mathrm{R} 4-\mathrm{b} 12.35-\mathrm{p} 2.05+\mathrm{n} 4.4$

$\mathbf{R} 3=\mathrm{R} 4+\mathrm{m} 6.9-\mathrm{v} 4.65 ;$

$\mathbf{R 5}=\mathrm{R} 5+\mathrm{m} 5.3$;

$\mathbf{R 6}=\mathrm{R} 4+\mathrm{m} 7.05-\mathrm{v} 4.65$;

$\mathbf{R} 7=\mathrm{R} 4+\mathrm{g} 11.05$

$\mathbf{R} 8=\mathrm{R} 4-\mathrm{f} 1.55-\mathrm{v} 4.65$;

MU1 = MU2 + a 2.1;

$\mathrm{T} 2=\mathrm{T} 1+\mathrm{h} 10.3+\mathrm{s} 1.6$

PA 2 = PA1 + g10.4-b12.35 +h10.3;

PA3 = PA1 - b12.35 + h10.3 +h12.35-

$+\mathrm{m} 12.4$.

R6) than it was to the other haplotypes found in $P$. rutulus (R1 and R2). All mtDNAs of these two species showed divergences of 1 per cent or less. $P$. glaucus and $P$. alexiares mtDNAs were also very similar (0.4-0.8 per cent). Divergences between all other pairs of species were more substantial (1.9-5.1 per cent).

In the $P$. troilus group, mtDNAs of separate subspecies were very similar $(0.4 \%$ for $P$. troilus and 0.6-0.8 per cent for $P$. palamedes). Haplotypes of different species of the $P$. troilus group showed much greater divergences than within the $P$. glaucus group, with divergences among the mtDNAs of $P$. troilus, $P$. palamedes and $P$. pilumnus ranging from 7.2 to 9.6 per cent.

\section{Genetic network}

When restriction sites were considered as unordered characters for phylogenetic analyses, a single most parsimonious network was found by a branch and bound search of the full set of 23 haplotypes (Fig. 2). The consistency index of this tree was 0.67 , excluding uninformative characters.
The gene network supported the separation of mtDNA haplotypes found in $P$. canadensis from a clade including mtDNAs of $P$. glaucus and $P$. alexiares. Within $P$.g. glaucus, the Florida populations are sometimes referred to as a separate subspecies, $P$. g. australis (Scriber et al., 1991); however, the $\mathrm{G}_{1}$ haplotype was found in both Maryland and Florida. Within $P$. canadensis, Alaskan and Yukon populations are also sometimes recognized as a separate subspecies, $P . g$. arcticus. The phylogenetic relationship of the $\mathrm{G}_{5}$ haplotype, from Alaska, showed only a single restriction site difference from the $\mathrm{G}_{4}$ haplotype, which was found in Alberta and New York.

Each of the five $P$. eurymedon specimens had a different haplotype, and the six $P$. rutulus specimens had three haplotypes. Interestingly, the mtDNAs of $P$. rutulus and $P$. eurymedon appeared to form a single clade, but the mtDNAs of neither $P$. rutulus nor $P$. eurymedon were monophyletic.

\section{mtDNA versus allozymes}

In order to facilitate comparison between my findings and those of Hagen \& Scriber (1991), the haplotype dataset and allozyme dataset were condensed to 11 groups corresponding to taxonomic species or major subspecies (Fig. 3). Genetic distance comparisons of mtDNA were accomplished by averaging values within the 11 taxonomic groups. In some cases these groups did not correspond to monophyletic mtDNA lineages; 


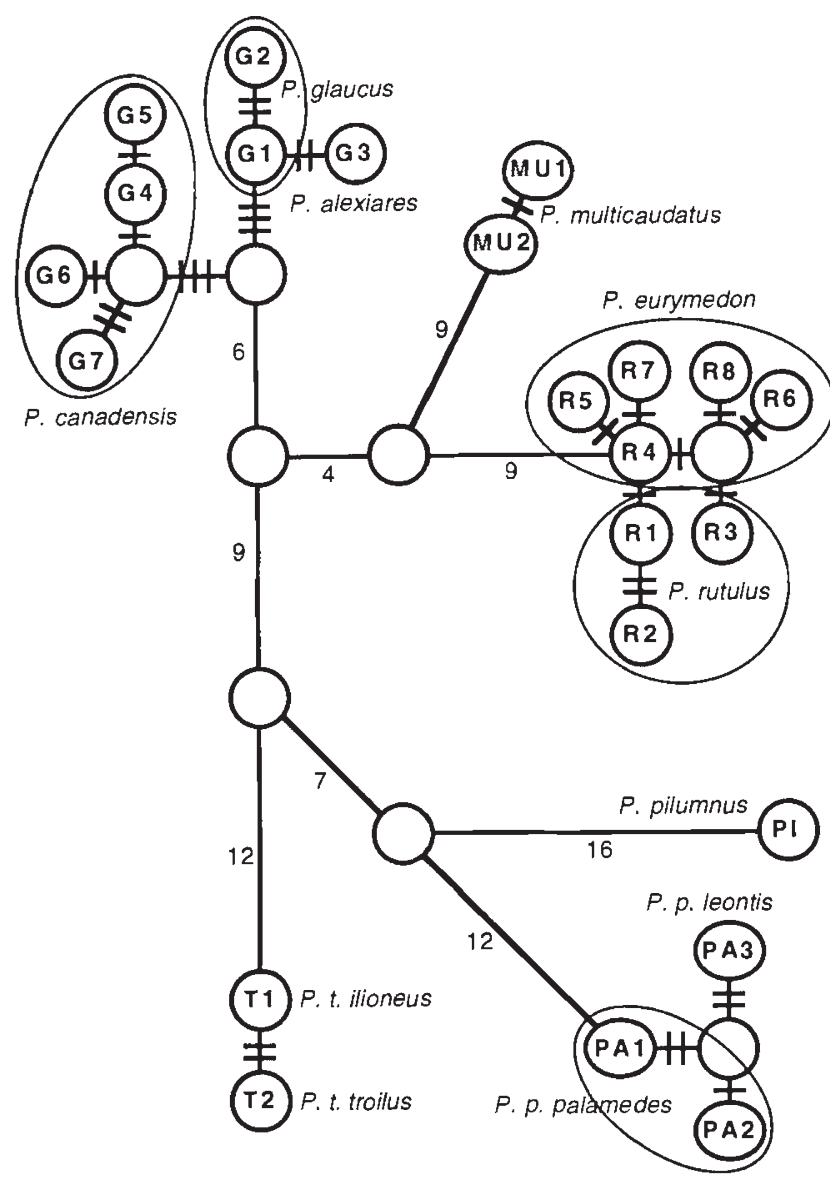

Fig. 2. Parsimony network of mtDNA haplotypes. Codes in circles refer to haplotypes of specimens surveyed (listed in Table 1). Numbers or bars on branches indicate numbers of restriction site changes (apomorphies). Branch lengths are adjusted in proportion to numbers of site changes. Species identifications of butterflies are indicated beside their haplotypes.

the mtDNAs of $P$. glaucus, $P$. eurymedon, $P$. rutulus, and $P$. p. palamedes were paraphyletic (Fig. 2). Parsimony analysis using PAUP $3.0 \mathrm{q}$ (Swofford, 1991) was performed on all haplotypes in the $P$. glaucus and $P$. troilus groups. Figure 3 includes a consensus tree based on heuristic searches of 500 bootstrap resamplings of the 23 haplotypes, with restriction sites considered as unordered characters. The consensus tree was rooted at the midpoint between the two most distant nodes.

The cladogram of allozyme data was redrawn from Hagen \& Scriber's (1991) figure, whereas the UPGMA phenogram of Nei's distances was recalculated from their table of Nei's genetic identities. The topology of the $P$. glaucus group in the phenogram in Fig. 3 differs from the branching pattern depicted in Hagen \&

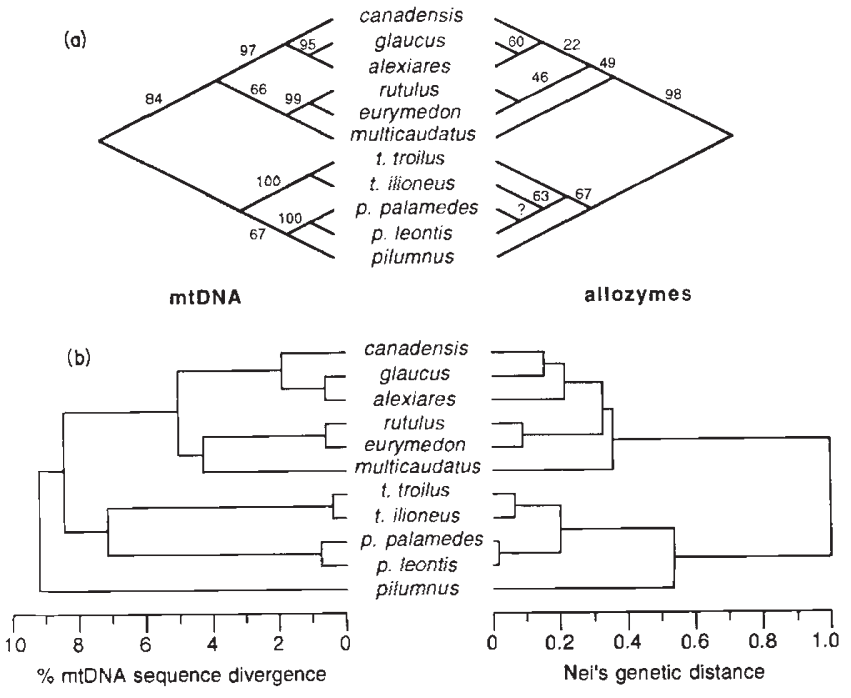

Fig. 3 Comparison of trees obtained from analysis of mtDNA, on the left, versus allozymes, on the right. Cladograms (a) are at the top, with numbers along branches referring to percent bootstrap support for particular groupings. UPGMA phenograms (b) are at bottom. The phenogram of mtDNA genetic divergences is calculated as $d$ of Nei \& Tajima (1983). The allozyme cladogram is redrawn from Hagen \& Scriber (1991) and the phenogram is recalculated from their table of Nei's standard genetic identities.

Scriber's (1991) phenogram, and now shows a closer correspondence to their cladogram.

The mtDNA and allozyme cladograms differed at three points. The mtDNA phylogeny weakly supported a sister group relationship for $P$. multicaudatus with $P$. rutulus $+P$. eurymedon, rather than branching off basally below the rest of the $P$. glaucus group. The mtDNA phylogeny also weakly supported a sister group relationship for $P$. pilumnus with $P$. palamedes, rather than with both $P$. palamedes and $P$. troilus. There was strong support from mtDNA for the monophyly of $P$. troilus, without any paraphyletic relationship with $P$. palamedes. Based on bootstrapping analyses, the branching pattern of the mtDNA phylogeny was, in general, much better supported than was the branching pattern of the allozyme phylogeny.

The UPGMA phenograms generated from pairwise genetic distances also showed good correspondence. The phenogram of mtDNA distances differed from the mtDNA cladogram in that $P$. pilumnus was basal to both the $P$. troilus and $P$. glaucus groups. The allozyme phenogram showed better agreement with mtDNA with respect to the distance relationships of $P$. troilus and $P$. palamedes, but poor agreement within the $P$. glaucus group. 


\section{Discussion}

\section{$m t D N A$ and species boundaries}

Most traditional species in the $P$. glaucus and $P$. troilus groups are characterized by discrete clusters of mtDNA haplotypes. $P$. rutulus and $P$. eurymedon were exceptions, even though there appears to be no question that they are separate species. $P$. eurymedon adults have a pale yellow coloration that distingishes them from all other $P$. glaucus group species. This colour trait reduces courtship of $P$. eurymedon females by males of $P$. multicaudatus (Brower, 1959b). It is reasonable to expect that the same is true of $P$. eurymedon and $P$. rutulus, but the necessary studies have not yet been done. $P$. eurymedon and $P$. rutulus also have different male genitalia (Brower, 1959a) and their first instar larvae differ in their survivorship on several host plants (Scriber et al., 1991). The two species overlap across virtually all of their range and viable hybrid adults of both sexes can be produced by hand pairing (Scriber $e t$ al., 1990), but very few natural hybrids have been found (Wagner, 1978).

Relationships among the mtDNA haplotypes of $P$. rutulus and $P$. eurymedon suggest that either:(i) mtDNA polymorphism has been retained through the speciation of $P$. rutulus and $P$. eurymedon; or (ii) at least two mtDNA introgression events have occurred between $P$. rutulus and $P$. eurymedon, followed by elimination of the original mtDNAs in one species. Allozyme differences between $P$. eurymedon and $P$. rutulus are small (Fig. 3), and neither alternative can easily be excluded.

$P$. glaucus and $P$. alexiares also have very similar mtDNA. $P$. glaucus overlaps a substantial part of the range of $P$. alexiares in northern Mexico but the extent to which the species maintain their integrity along the zone of contact seems uncertain (Beutelspacher \& Howe, 1984). In contrast, the extent of allozyme differences between them is greater than between $P$. glaucus and $P$. canadensis (Fig. 3 ), indicating significant divergence of nuclear genes.

A partial lack of correspondence between traditional species boundaries and mtDNA haplotype distributions has also been found in insects such as Drosophila (Powell, 1983; Aubert \& Solignac, 1990), cicadas (Martin \& Simon, 1990) and weevils (Boyce, 1990). These examples suggest that it will be interesting to survey the mtDNA of $P$. eurymedon $/ P$. rutulus and $P$. glaucus $/ P$. alexiares species pairs throughout their range, to determine whether any older mtDNA lineages can be found and under what conditions they may have been preserved.

\section{$m t D N A$ and the Haldane effect}

$P$. rutulus/ $P$. eurymedon and $P$. glaucus/ $P$. alexiares are among the few pairs of closely related Papilio species that do not show a Haldane effect (Ae, 1979; Table 2). In contrast, deficiency of females is pronounced in hybrids between $P$. glaucus and the three western species $-P$. eurymedon, $P$. rutulus and $P$. multicaudatus. There is a smaller, but significant, Haldane effect between $P$. glaucus and $P$. canadensis (Hagen \& Scriber, 1993).

In hybrids between $P$. glaucus and $P$. canadensis, or between $P$. glaucus and the western species, ecologically important differences like diapause and female mimetic wing coloration are located on the sex chromosomes (Hagen \& Scriber, 1989). In contrast, one of the most important genetic differences between $P$. eurymedon and $P$. rutulus appears not to be controlled by $\mathrm{X}$-linked genes, since female $\mathrm{F}_{1}$ hybrids from both crosses between $P$. glaucus and $P$. eurymedon have a wing color that is nearly as yellow as that of $P$. glaucus (West \& Clarke, 1988). The correlation between mtDNA differences and Haldane effect supports the expectation that differential elimination of females will lead to conformance of mtDNA differences with species boundaries. The correspondence of both factors with the $\mathrm{X}$ effect suggests the possibility that interactions between cytoplasmic factors and $\mathrm{X}$-linked genes are involved in the maintenance of species boundaries in these species (see Virdee \& Hewitt, 1992, for an example in grasshoppers). However, mtDNA differences may also be due to selection against combinations of autosomal genes and cytoplasmic traits.

P. multicaudatus is a case that counters the correlation of mtDNA differences with the Haldane effect. Possible natural hybrids between $P$. rutulus and $P$. multicaudatus have been reported (Brower, 1959a; Garth \& Tilden, 1986) and preliminary evidence suggests that there is no Haldane effect in crosses

Table 2 Correspondence between mtDNA differences, Haldane effect and X effect in species pairs of the $P$. glaucus group (West \& Clarke, 1988; Scriber et al., 1990; Hagen \& Scriber, 1993)

\begin{tabular}{|c|c|c|c|}
\hline & $\begin{array}{l}\text { mtDNA } \\
\text { differences }\end{array}$ & $\begin{array}{l}\text { Haldane } \\
\text { effect }\end{array}$ & $\begin{array}{l}X \\
\text { effect }\end{array}$ \\
\hline P. glaucus $\times$ canadensis & Yes & Yes & Yes \\
\hline P. glaucus $\times$ rutu./eury./mult. & Yes & Yes & Yes \\
\hline$P$. glaucus $\times$ alexiares & No & No & $?$ \\
\hline$P$. rutulus $\times$ eurymedon & No & No & No? \\
\hline P. multicaudatus $\times$ rutu./eury. & Yes & No & $?$ \\
\hline
\end{tabular}


between $P$. multicaudatus and either $P$. rutulus or $P$. eurymedon (Scriber et al., 1990). Yet the mtDNA of the two specimens of $P$. multicaudatus examined in this study was very distinct. I suggest that both allozymes and mtDNA indicate genetic divergences are so extensive that a large number of genes now contribute to genetic barriers to introgression, obscuring any early contribution that might have been due to genes on sex chromosomes.

To date, mtDNA differences, Haldane effect and $\mathrm{X}$ effect have been studied in only two other species groups of Lepidoptera, including the Papilio machaon group (Ae, 1979; Thompson, 1988; Sperling, 1993) and the Choristoneura fumiferana group (Harvey, 1985; Sperling \& Hickey, unpublished). Both cases show correspondence between all three phenomena. A correlation between distinct mtDNA and the Haldane effect or X effect should hold for other closely related species of organisms in which females are the heterogametic sex, including a variety of vertebrates, invertebrates and even plants (Bull, 1983; Tegelström \& Gelter, 1990).

\section{mtDNA and species phylogenies}

Unlike mtDNA, allozymes survey a number of parts of the nuclear genome. Hence they can be expected to give a more representative picture of genetic divergence among populations. However, as Buth (1984) has stated, 'there has been no consensus on the appropriate treatment of electrophoretic data in phylogenetic studies, and problems have persisted at a variety of levels'. Hagen \& Scriber (1991) encountered some of these problems in their survey of Papilio allozymes, including incomplete resolution of alleles and the need for arbitrary cutoffs for converting frequency differences into discrete character states.

In contrast, the abundant, clearly resolved variation in mtDNA, together with the absence of recombination, makes the molecule ideal for phylogenetic analysis. The mtDNA survey distinguished 102 restriction sites, each of which was treated as one character with two states. In comparison, the 26 loci in the allozyme survey were each treated as one character, with 1-10 allelic character states per locus. Bootstrap support was higher for the mtDNA phylogeny than the allozyme phylogeny. However, the fact that mtDNA may not be respresentative of the rest of the genome is well illustrated by $P$. rutulus and $P$. eurymedon, which appear to share their mtDNA in spite of clear morphological, behavioural and allozyme differences. Nonetheless, the paraphyletic relationship indicated by allozymes for the $P$. troilus subspecies, in spite of strong support for monophyly on the basis of both morphology and mtDNA, indicates that allozymes may also fail to elucidate relationships at this level.

The question remains: is it more informative to have an unclear picture of a large part of the genome, or a clear picture of a small part of the genome? Judging from a comparison of allozymes and mtDNA against the classical species delineations in the $P$. glaucus and $P$. troilus groups, analysis of mtDNA variation is approximately as effective for determining species limits and relationships as is analysis of a battery of allozyme loci.

\section{Acknowledgements}

I greatly appreciate the special efforts made by people who obtained live or frozen swallowtails for me, including M. Ayres, M. Carter, M. Evans, P. Feeny, M. Furr, R. Hoebeke, R. Lederhouse, D. McCorkle, M. Peterson, M. Scriber, A. Shapiro, B. Sperling and C. Yoon. I thank S. Bogdanowicz for advice in the lab, R. Hagen and R. Lederhouse for discussion, and $\mathrm{K}$. Brown, P. Feeny, R. Harrison and D. Hickey for comments on various forms of the manuscript. This study was supported by grants from the National Science Foundation (BSR-8914620 to F. S., BSR-8906707 to R. G. Harrison and BSR-8516832 to P. Feeny).

\section{References}

AE, S. A. 1979. The phylogeny of some Papilio species based on interspecific hybridization data. System. Entomol., 4, $1-16$.

AUBERT, J. AND SOLIGNAC, M. 1990. Experimental evidence for mitochondrial DNA introgression between Drosophila species. Evolution, 43, 1192-1208.

AVISE, J. C., ARNOLD, J., BALL, R. M., BERMINGHAM, E., LAMB, T., NEIGEL, J. E., REEB, C. A. AND SAUNDERS, N. C. 1987. Intraspecific phylogeography: the mitochondrial DNA bridge between genetics and systematics. Ann. Rev. Ecol. System. 18, 489-522.

AVISE, J. C. 1989. Gene trees and organismal histories: a phylogenetic approach to population biology. Evolution, 43, 1192-1208.

AVISE, J. C. 1991. Ten unorthodox perspectives on evolution prompted by comparative population genetic findings on mitochondrial DNA. Ann. Rev. Genet., 25, 45-69.

BEUTELSPACHER, C. R. AND HOWE, w. H. 1984. Mariposas de Mexico. vol. 1. La Prensa Medica Mexicana, S. A., Mexico, D. F.

BOYCE, T. M. 1990. Molecular evolutionary genetics of the bark weevils: speciation and mitochondrial DNA evolution. Ph. D. Thesis, Cornell University.

BROWER, L. P. 1959a. Speciation in butterflies of the Papilio glaucus group. I. Morphological relationships and hybridization. Evolution, 13, 40-63. 
BRower, L. P. 1959b. Speciation in butterflies of the Papilio glaucus group. I. Ecological relationships and interspecific sexual behavior. Evolution, 13, 212-228.

BulL, J. J. 1983. Evolution of Sex Determining Mechanisms. The Benjamin/Cummings Publ. Co., Menlo Park, California.

BUTH, D. G. 1984. The application of electrophoretic data in systematic studies. Ann. Rev. Ecol. Syst., 15, 501-522.

CHARLESWORTH, B., COYNE, J. A. AND BARTON, N. H. 1987. The relative rates of evolution of sex chromosomes and autosomes. Am. Nat. 130, 113-146.

COYNE, J. A. AND ORR, H. A. 1989. Two rules of speciation. In: Otte, D. and Endler, J. A. (eds) Speciation and its Consequences, Sinauer Assoc., Sunderland, Massachusetts, pp. 180-207.

COYNE, J., CHARLESWORTH, B. AND ORR, H. A. 1991. Haldane's rule revisited. Evolution, 45, 1710-1714.

FRANK, S. A. 1991. Haldane's Rule: A defense of the meiotic drive theory, Evolution, 45, 1714-1717.

GARTH, J. S. AND TILDEN, J. w. 1986. California Butterflies. University of California Press, Berkeley.

HAGEN, R. H. AND SCRiBER, J. M. 1989. Sex-linked diapause, color, and allozyme loci in Papilio glaucus: linkage analysis and significance in a hybrid zone. J. Hered, 80, 179-185.

HAGEN, R. H. AND SCRIBER, J. M. 1991. Systematics of the Papilio glaucus and $P$. troilus species groups (Lepidoptera: Papilionidae): inferences from allozymes. Ann. Ent. Soc. Am., 84, 380-395.

HAGEN, R. H. AND SCRIBER, J. M. 1993. Sex chromosomes and speciation in tiger swallowtails. In: Scriber, J. M., Tsubaki, Y. and Lederhouse, R. C. (eds) The Ecology and Evolutionary Biology of the Papilionidae. Scientific Publishers, Inc., Gainsville, Florida. (in press)

HAGEN, R. H., LEDERHOUSE, R. C., BOSSART, J. L. AND SCRIBER, J. M. 1992. Papilio canadensis and $P$. glaucus (Papilionidae) are distinct species. J. Lepid. Soc., 45, 245-258.

HALDANE, J. B. S. 1922. Sex ratio and unisexual sterility in hybrid animals. J. Genetics, 12, 101-109.

harrison, R. G. 1991. Molecular changes at speciation. Ann. Rev. Ecol. System., 22, 281-308.

HARRISON, R. G., RAND, D. M. AND WHEELER, w. C. 1987. Mitochondrial DNA variation in field crickets across a narrow hybrid zone. Mol. Biol. Evol., 4, 144-158.

HARVEY, G. T. 1985. The taxonomy of the coniferous Choristoneura (Lepidoptera: Tortricidae): A review. In: Sanders, C. J., Stark, R. W., Mullins, E. J. and Murphy, J. (eds) Recent Advances in Spruce Budworms Research. Proc. CANUSA Spruce Budworms Research Symposium, Bangor, Maine. Canad. Forestry Service, Ottawa, Ontario, pp. 16-48.

MARTIN, A. AND SIMON, C. 1990. Differing levels of amongpopulation divergence in the mitochondrial DNA of periodical cicadas related to historical biogeography. Evolution, 44, 1066-1080.
MORITZ, C., DOWLING, T. E. AND BROWN, w. M. 1987. Evolution of animal mitochondrial DNA: Relevance for population biology and systematics. Ann. Rev. Ecol. System., 18, 269-292.

NEI, M. AND TAJIMA, F. 1983. Maximum likelihood estimation of the number of nucleotide substitutions from restriction sites data. Genetics, 105, 207-217.

POWELL, J. R. 1983. Interspecific cytoplasmic gene flow in the absence of nuclear gene flow: evidence from Drosophila. Proc. Natl. Acad. Sci. U.S.A., 80, 492-495.

READ, A. AND NEE, S. 1991. Is Haldane's rule significant? Evolution, 45, 1707-1709.

SCRIBER, J. M., DOWELL, R. V., LEDERHOUSE, R. C. AND HAGEN, R. H. 1990. Female color and sex ratio in hybrids between $\mathrm{Pa}$ pilio glaucus glaucus and $P$. eurymedon, $P$. rutulus and $P$. multicaudatus (Papilionidae). J. Lepid. Soc., 44, 229-244.

SCRIBER, J. M., LEDERHOUSE, R. C. AND HAGEN, R. H. 1991. Foodplants and evolution within Papilio glaucus and Papilio troilus species groups (Lepidoptera: Papilionidae). In: Price, P. W., Lewinsohn, T. M., Fernandes, G. W. and Benson, W. W. (eds) Plant-Animal Interactions: Evolutionary Ecology in Tropical and Temperate Regions. John Wiley, New York, pp. 341-373.

SPERLING, F. A. H. 1990. Natural hybrids of Papilio: poor taxonomy or interesting evolutionary phenomenon? Canad. J. Zool., 68, 1790-1799.

SPERLING, F. A. H. 1993. Mitochondrial DNA phylogeny of the Papilio machaon species group (Lepidoptera: Papilionidae). In: Ball, G. E. and Danks, H. V. (eds) Systematics in Support of Entomology Mem. Ent. Soc. Canad., 165, 233-242.

SwOFFORD, D. L. 1991. PAUP: Phylogenetic Analysis Using Parsimony, Version 3.0 Q. Computer program distributed by the Illinois Natural History Survey, Champaign, Illinois.

TEGELSTRÖM, H. AND GELTER, H. P. 1990. Haldane's rule and sex biased gene flow between two hybridizing flycatcher species (Ficedula albicollis and F. hypolleuca, Aves: Muscicapidae). Evolution, 44, 2012-2021.

THOMPSON, J. N. 1988. Evolutionary genetics of oviposition preference in swallowtail butterflies. Evolution, 42, 1223-1235.

VIRDEE, S. R. AND HEWITT, G. M. 1992. Postzygotic isolation and Haldane's rule in a grasshopper. Heredity, 69, 527-538.

WAGNER, W. H., Jr. 1978. A probable natural hybrid of Papilio eurymedon and $P$. rutulus (Papilionidae) from Idaho. $J$. Lepid. Soc., 32, 226-228.

WEST, D. A. AND CLARKE, C. A. 1987 (1988). Suppression of the black phenotype in females of the $P$. glaucus group (Papilionidae). J. Res. Lepid., 26, 187-200.

ZOUROS, E., FREEMAN, K. R., BALL, A. O. AND POGSON, G. H. 1992. Direct evidence for extensive paternal mitochondrial DNA inheritance in the marine mussel Mytilus. Nature, 369, 412-414. 